\title{
Innovation and Change in Public Administration
}

\author{
J. A. Oliveira Rocha1, Gonçalves J. B. Zavale² \\ ${ }^{1}$ Universidade Lusófona do Porto, Porto, Portugal \\ ${ }^{2}$ Universidade Joaquim Chissano, Maputo, Mozambique \\ Email: jaoliveirarocha@gmail.com,dambuzaz@yahoo.com.br
}

How to cite this paper: Rocha, J. A. O., \& Zavale, G. J. B. (2021). Innovation and Change in Public Administration. Open Journal of Social Sciences, 9, 285-297. https://doi.org/10.4236/jss.2021.96021

Received: October 16, 2020

Accepted: June 22, 2021

Published: June 25, 2021

Copyright (C) 2021 by author(s) and Scientific Research Publishing Inc. This work is licensed under the Creative Commons Attribution International License (CC BY 4.0).

http://creativecommons.org/licenses/by/4.0/ cc (i) Open Access

\begin{abstract}
This article defines and examines the concept of innovation, as a radical change in Public Administration that can be defined as translating into new processes, new technologies, creation of new products and introduction of new values in Public Administration. New public management models mean forms of innovation, new paradigms and new forms of management. This discussion examines the characteristics of each model through history, specifically underlining the break introduced by the New Public Management Model which meant a complete change in the public management philosophy. In analyzing the change process and strategy, whose impetus falls to the political power, we will take into account social or economic ruptures and the pressure of citizens. Finally, some instruments and incentives for change are made explicit and we show that change is the responsibility of management; and, once introduced, such change must be "frozen" through legislative instruments.
\end{abstract}

\section{Keywords}

Innovation, Change Public Management and Public Administration

\section{Introduction}

In this article, we define innovation and analyze the transformations imposed by the different models of Public Administration and in what sense we can call innovation and not change as already mentioned in this section. Portugal is our main case study. The aim of the study was to understand innovation in public administration, the results of some instruments and incentives for change in public administration. This is a document review study based on the use of the Qualitative or Phenomenological Paradigm, of a descriptive and exploratory na- 
ture, developed based on documentary and bibliographic methods. The analysis and treatment of data consisted of the content analysis technique. After the collection of documentary (and bibliographic) data, its analysis was carried out, based on the assumptions of that content analysis technique, as this technique, within the quantitative paradigm, counts the frequency of the occurrence of certain terms, statements/speeches and references that occur in a given text that deserved our analysis.

Finally, in relation to data collection; this took place at the end of 2019 to 2020 , with the purpose of conceptualizing innovation, as a radical change that seems to translate into a new procedural, technological approach and new value anchored in the New Public Management. In addition, another objective of the article also aimed to analyze the change process and the strategy based on political power, considering a social, economic rupture and pressure from citizens. Main results: In fact, some instruments and incentives for change are listed. Finally, we present the conclusions of the study.

\section{Concept of Innovation}

Osborne \& Brown (2011) define innovation in public services, as the introduction of new elements in public services in the form of new knowledge, new organizations and new forms of management. Thus, innovation represents a discontinuity with the past. According to other authors, innovation means discontinuous change. Vries, Tummers, \& Bekkers (2016) stress that there is no precise definition and accept instead that it is a discontinuity in relation to the past. Such discontinuity may be in the processes, adoption of new technologies, creation of new products and services and introduction of new concepts. The objective is to increase efficiency and effectiveness, while also increasing citizen satisfaction.

When innovation translates into new ways of operating in Public Administration, there is talk of a paradigm shift and the appearance of a new model of public management. These models have an internal logic that translates into new concepts, new ways of operating, new management instruments, new objectives and new values. Therefore, when examining the models, it becomes possible to identify the disruptions and innovations that followed.

Some experts (see, for example, Hartley (2005)), referring to these leaps in innovation, speak of three public management models: Traditional administration, or the classic model, New Public Management (NPM), and Network Governance. We could add another one: the Neo Weberian model.

\section{The Classic Model}

The traditional, or classical, model for Public Administration dates back to the French Revolution and the theory of the separation of powers where it is up to the Public Administration to implement the policies as defined by the political power. There is, therefore, a separation between politics and administration. 
Wilson (1887) calls it a dichotomy. Furthermore, civil servants are governed by a statute that was supposed to guarantee their neutrality. In anglophile countries, from the nineteenth century onwards, the admission of civil servants was controlled by a civil service commission, which guaranteed a meritocracy.

This model was characteristic of a liberal state, which did not want to intervene in economic and social life, and where relations between the state and citizens were regulated by administrative law. However, the construction of the welfare state has made this model atypical, not only because of the increase in the number of employees and their technical quality, but also because of the increase in the functions of the state. Since then, politics as become an easy prey for bureaucracy, and in practice the difference between politics and administration has effectively disappeared.

The financial crisis of the late 1970s forced the adoption of alternative measures to the traditional administrative model and instead consider the model of New Public Management (Hood, 1991).

\section{New Public Management}

The financial crisis of the "State" in the late seventies has been attributed to the excessive weight of the Public Administration, as well as to its apparent inefficient management.

The first measures basically consisted of the privatization of public companies, assuming that, in this way, citizens pay a cheaper price. We now know this is not true, unless these privatized activities are regulated ensuring competition and transparency in pricing. There are currently 17 regulatory bodies in Portugal, ranging from Banco de Portugal to the Health Regulatory Authority.

The second set of ideas, which represented a revolution in Public Administration and consisted of the introduction of techniques and models of business management, ranging from cost accounting, performance evaluation, emphasis on results to the detriment of formalities, and the fragmentation of large units of administration with an emphasis on their autonomy (see the proliferation of public corporation hospitals and university foundations).

From the point of view of labor relations, the employment contract gave way to the individual labor contract, which is the same or similar to that of the companies.

In practical terms, the New Public Management translated into three dominant dimensions:

- Primacy of the Market. The adoption of market mechanisms includes user fees, out-sourcing and vouchers, or their equivalents;

- Adoption of agency models with abandonment of hierarchical structures. An agency is defined as an executive unit that provides a service to the state, for which it is financed, but has no administrative tutelage, being evaluated according to the results (see, for example, public corporation hospitals); and

- Performance indicators. With insistence on results and not on compliance 
with legal formalities.

In most OECD countries, these reforms embodied a new paradigm that substituted the juridical paradigm. However, the changes were radical and did not always happen, as was the case in the Southern European countries.

\section{Network Governance (NPG)}

It is true that the New Public Management model brought benefits to public services, helping to rationalize spending and reduce the number of employees. Despite the improvements with the adoption of the new paradigm, in the mid-nineties there was a crisis in Public Administration, leading to many asking whether it was due to the new management model. In fact, it was found that as governments reduced responsibility for the functioning of public services their administrations became difficult to control; besides that autonomy and competition naturally reduced coordination. These were the contradictions and limitations that led to thinking about changing public management resulting in Network Governance. This was characterized by continuous change, citizen participation, decisions made by different actors, partnerships between the public and the private and the dominant role of the State; and it represented an attempt to overcome the negative consequences of New Public Management, especially in Anglophile countries (Peters, 2008).

The international financial crisis changed this new approach, for many this was a mere reformulation of the New Public Management.

\section{The 2008 Financial Crisis and New Public Management Model}

The laxity of the State's regulatory role, the indiscriminate adoption of public-private partnerships, the use of high-risk financial instruments, for example, swaps, and the outsourcing of public services were by-products of the poor implementation of the New Public Management model. Therefore, especially in continental and central Europe, although in different circumstances, a new public management paradigm called Neo Weberian was adopted.

In practical terms, the concept contains Weberian elements, identifiable with traditional administration, such as the reaffirmation of the State as a facilitator of solutions; reaffirmation of the importance of Administrative Law; and preserving the idea of public service. The Neo Weberian model also includes elements characteristic of the New Public Management model, such as the importance given to citizens to the detriment of rules and regulations; overcoming representative democracy by including consultation mechanisms; continued insistence on obtaining results; and professionalization of public management, so that the manager is not a mere expert in laws, but is oriented to the needs of their citizens.

In terms of human resource management, the Neo Weberian model translates into greater centralization and coordination, tempering political trust with me- 
ritocracy.

In fact, the 2008 crisis accentuated the centralization of the State increasing the flexibility of human resources management and reducing the number of employees.

In the Portuguese case, the Recruitment and Selection Committee for Public Administration (CRESAP) can be understood as a Neo Weberian element, inasmuch as it adopts the choice of public directors and managers based on merit, tempered with a restricted political choice. Political power has the ability to choose from the top three in the case of directors general and deputy directors, or similar; and, in the case of public managers, to oppose the opinion of CRESAP. In this case, it remains in the control of public opinion.

Having defined the models (Table 1), it is now important to analyze how one jumps from one model to another.

However, change does not always happen with a break in traditional processes. In many cases, many of the processes have resisted change, and the change is often merely incremental and not a true innovation. Furthermore, great innovations are often absorbed by each country's culture. Thus, countries of Anglo-Saxon culture have completely changed the traditional administration, insisting on accountability and the proliferation of independent organizations. The Nordic countries imported the instruments of business management in order to save the welfare state. Continental European countries have adjusted the new measures to a Weberian tradition. In turn, in the countries of southern Europe, where Portugal is included, the change has been very slow, given that innovation translates into a legal language that, in fact, prevents change.

Table 1. Principal models of public administration.

\begin{tabular}{|c|c|c|c|c|}
\hline & $\begin{array}{l}\text { Classical Administration } \\
\text { (Bureaucratic Model) }\end{array}$ & New Public Management Model & $\begin{array}{l}\text { Governance } \\
\text { Model (NPG) }\end{array}$ & Neo-Weberian Model \\
\hline State Type & $\begin{array}{l}\text { Liberal. Although after } \\
\text { the Second World War it } \\
\text { evolved into the welfare state }\end{array}$ & Neoliberal model & $\begin{array}{c}\text { Plural and } \\
\text { Coordinating State }\end{array}$ & Neo-Weberian State \\
\hline $\begin{array}{l}\text { Organizational } \\
\text { structure }\end{array}$ & $\begin{array}{l}\text { Hierarchization, centralization } \\
\text { and control }\end{array}$ & $\begin{array}{l}\text { Decentralization and management } \\
\text { autonomy of organizations }\end{array}$ & $\begin{array}{l}\text { Network } \\
\text { management }\end{array}$ & $\begin{array}{c}\text { Combination of } \\
\text { centralized structure } \\
\text { with levels of autonomy }\end{array}$ \\
\hline $\begin{array}{l}\text { Human resource } \\
\text { management }\end{array}$ & $\begin{array}{l}\text { Based on Administrative Law } \\
\text { Contracts for life }\end{array}$ & $\begin{array}{l}\text { Individual employment contract, } \\
\text { similar to the Labor Code. Recruitment } \\
\text { and selection of organizational } \\
\text { responsibility, depending on budget }\end{array}$ & $\begin{array}{l}\text { Negotiated } \\
\text { management }\end{array}$ & $\begin{array}{l}\text { Continuation of individual } \\
\text { employment contract, but } \\
\text { centralized recruitment }\end{array}$ \\
\hline $\begin{array}{l}\text { Appointment } \\
\text { of officers }\end{array}$ & Political trust & Based on merit & $\begin{array}{c}\text { Choice based } \\
\text { on leadership skills }\end{array}$ & $\begin{array}{l}\text { Hybrid, based on merit } \\
\text { and political choice }\end{array}$ \\
\hline $\begin{array}{l}\text { Management } \\
\text { responsibility }\end{array}$ & $\begin{array}{l}\text { For compliance with rules and } \\
\text { procedures }\end{array}$ & Getting results & $\begin{array}{l}\text { Sharing with } \\
\text { other actors }\end{array}$ & $\begin{array}{l}\text { Shared: political } \\
\text { and professional }\end{array}$ \\
\hline
\end{tabular}

Source: Prepared by authors. 
Regardless of the variations of innovations in administrative reform, it is then necessary to analyze how innovation is processed and what instruments and incentives are involved, since it is a management process and cannot be decreed by the State.

\section{Change Process and Strategy}

Peter Drucker (1986), referring to public organizations, underlines that they do not innovate and are intrinsically conservative. Innovations are imposed by people outside the services, or by catastrophes. As a rule, public administration reforms are initiated by the government as a result of a crisis. An example of which is the case of Great Britain.

The government published a white paper on the state of Public Administration and the need to change the way it worked. Of course, the British government's manifestation resulted from a crisis in public finances and the responsibility attributed to bureaucracy for a current of economic thought that saw public management and the welfare state as the cause of the crisis (Figure 1).

At the same time, a situation of disruption and catastrophe was created.

It is possible to identify a clear strategy, designed to adopt the New Public Management model, and which contains three elements: remodeling of the civil service environment; organizational culture reform; and reaffirmation of political control over employees (Rocha, 2010).

The first strategy consisted of limiting the power of the civil service, reducing its influence, through privatization, deregulation and non-intervention programs. In this way, not only the Administration's link to economic activity was limited, but also the number of employees was reduced. The second objective was to weaken the power of employees, by reducing wages, controlling employees' relations with their customers, as well as weakening unions.

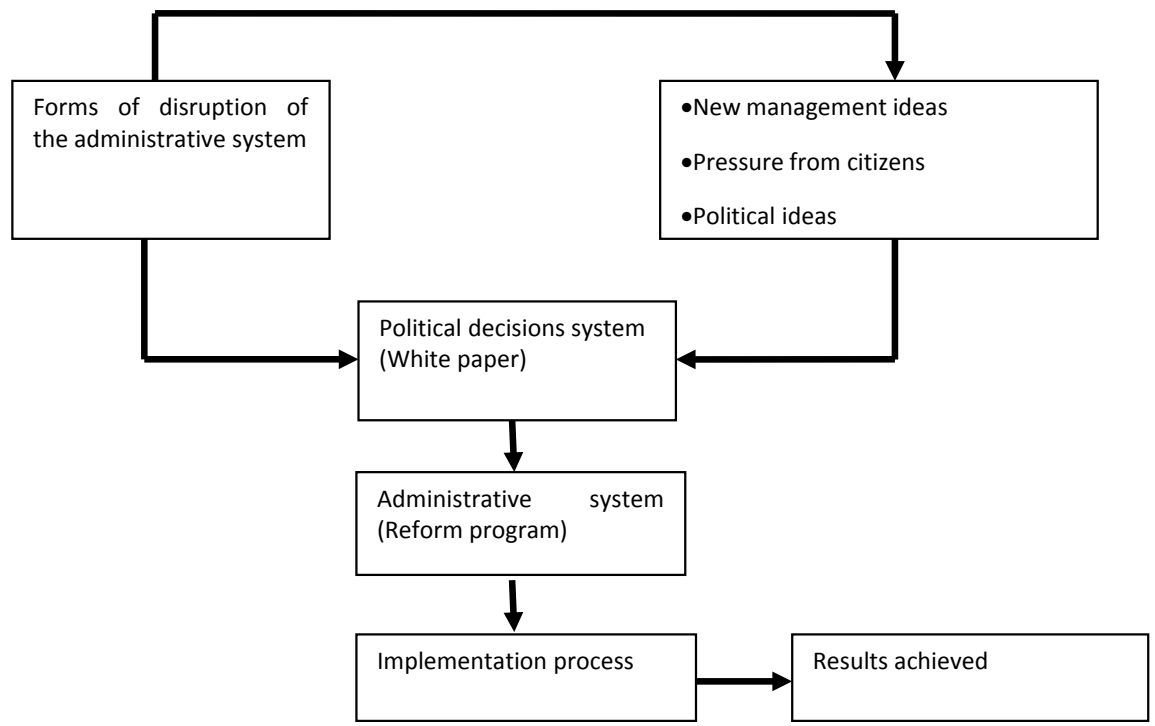

Figure 1. Management reform. Source: Adapted from Pollitt \& Bouckaert (2011). 
The second strategy consisted of reforming the ideological organizational culture, with changes to the references to the Keynesian model and to the principles of the welfare state.

That said, the Administration was weakened enough to accept the importation of business management processes and values.

It is a classic strategy developed by Lewin (1951), corresponding to the unfreezing stage, which should be followed by the change that ends with the refreezing of the new public management model.

The Portuguese case is, at least, formally similar. In 2004, the government issued a Resolution (Resolution of the Council of Ministers No. 53/2004, of 21 April) in which it developed a model for the reform of Public Administration, markedly based on a New Public Management perspective (Figure 2).

The first phase consisted of a State reengineering operation, which consisted of:

- Analysis of functions, in order to define the functional content of ministries and basic units.

- Selection of functions to internalize (concentrate or decentralize).

- Action proposal for functions designed to be outsourced.

After the reengineering of the State and Public Administration was carried out, management based on objectives was applied, both to the ministries and to the basic units.

This process was expected to result in improved quality and increased efficiency. Finally, the training of managers and officials would complementarily contribute to the change process.

The "freezing" of change would be achieved through the publication of several decree-laws, intended to explain the consequences of the new paradigm, for example, on the individual employment contract, performance evaluation (SIADAP), bonds, careers and remunerations, disciplinary status and public procurement.

However, it is important to recognize that the results of this strategy were not the same as in Great Britain. In the final part of our article (Rocha \& Araujo, 2007) we explain the reasons for this failure. First, there was an increase in party patronage, since the old statutory system was subject to great flexibility; second, privatizations increased the power of economic groups, with no counterweight to regulation; finally, the decrease in the weight of Public Administration represented the proletarianization of the middle class that depended on the State.

Pollitt \& Bouckaert (2011) believe that, although the NPM has presented itself as a universal recipe to solve the crisis of traditional Administration, this type of innovation cannot be generalized and universalized. There is strong evidence that the countries analyzed have different political and administrative systems (Table 2), as well as different administrative cultures that influence the trajectories of administrative reform. Many reforms, when transferred, are translated into a national reality. Hence the intensity of the reforms varied considerably from country to country. Anglophile countries were extremely active. A second 
Table 2. Short comparison of public administration systems.

\begin{tabular}{|c|c|c|c|c|c|}
\hline & France & United Kingdom & Germany & Sweden & Portugal \\
\hline \multirow{2}{*}{ Territory Organization } & Unitary State & Unitary State & Federal State & Unitary State & Unitary State \\
\hline & Centralized & Decentralized & Relatively decentralized & Very decentralized & Very centralized \\
\hline $\begin{array}{c}\text { Degree of Political/ } \\
\text { Management Separation }\end{array}$ & Reduced & Great & Great & Great & Reduced \\
\hline Main Coordinating Power & Ministerial offices & Administrative elites & $\begin{array}{l}\text { Principle of hierarchy and } \\
\text { professional officials }\end{array}$ & $\begin{array}{l}\text { Consensus-based } \\
\text { practices }\end{array}$ & $\begin{array}{l}\text { Ministers and } \\
\text { offices }\end{array}$ \\
\hline
\end{tabular}

Source: Rodrigues (2011: p. 208).

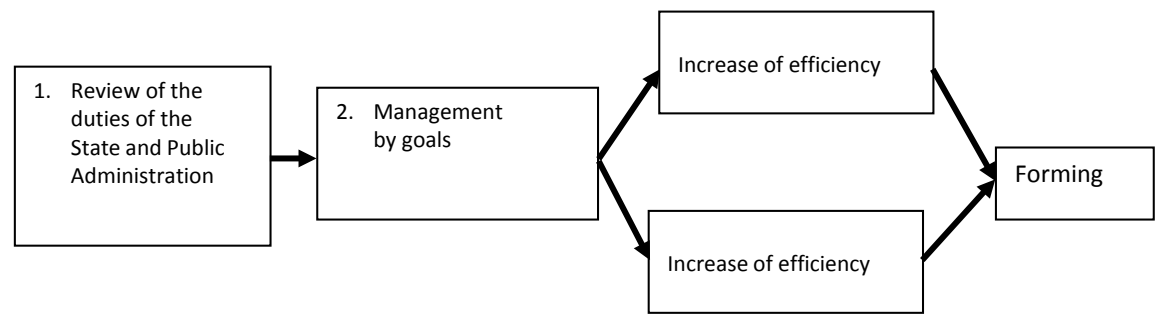

Figure 2. Reform strategy. Source: Resolution of the Council of Ministers, $n^{\circ}$ 53/2004, of 2 April.

group of countries were also active with the reform, but did not adopt all the mechanisms. These countries are France and Germany, Nordic countries, Holland and Canada. Thirdly, mention should be made of the states in transition, from central and Eastern Europe that wanted to implement some elements of the NPM, but crossing them with the Weberian tradition.

Kickert (2008) distinguishes between Napoleonic tradition (France and Germany) in which the State is the center of power and the Administration is uniform, centralized and hierarchical, governed by Administrative Law. Second, the four Southern European countries (Italy, Spain, Portugal and Greece) share a common set of cultural, social, economic and historical characteristics. Formalism and legalism dominated the relationship between the state and citizens. In turn, Peters (2008) develops the concept of the Napoleonic State. This model obeys administrative traditions, the first of which is the primacy of the State and centrality; second, prevalence of the law on management; third, no separation between politics and administration; fourth, career system; and finally, uniformity of laws applied to all employees.

Portugal, which fits in the trajectory of the reforms (Rocha \& Araujo, 2007: p. 592) southern European countries, obeys certain characteristics that explain:

- Assisted Capitalism, this means a close relationship between the State and economic groups.

- Political patronage in the choice of the leading cadres of Public Administration.

- Clientelism at the admission to the public service, not always through public tenders; and when it exists, it is often nothing more than formalism. 
- Non-rational distribution of administrative staff.

- Legalism and formalism.

- Lack of an administrative elite.

In short, there is some consistency in each group of countries in the way new models are imported and how these innovations are internalized, when in contact with national administrative systems and cultures (Lapuente \& Susuki, 2020).

\section{Instruments and Incentives for Change}

A broken situation, pressure from citizens and political will are not enough to bring about innovation and the move to a new model of Public Administration. Such changes occur with the use of certain management instruments along with incentives for change. In this context, public managers play a fundamental role (Gieske et al., 2020).

\section{Public Managers}

These play a fundamental role in executing change (Damanpour \& Schneider, 2011). Their recruitment and selection must take into account the objectives of changing policy. It is the managers who will involve employees in the process (Osborne \& Brown, 2005). Radical changes are not made with laws, hence also the importance that must be given to their training (Clausen \& Demircloglu, 2020).

The concerns with training existed in Portugal with the creation of the Senior Management Course in Public Administration (CADAP). The training became a requirement for acceptance in call for candidates, created by Ordinance No. $1141 / 2005$, of 8 November, although it could be temporarily replaced by shorter courses. This corresponded to a postgraduate degree in Public Administration. In addition to technical and leadership content, the course provided seminars designed to induce change, quality and innovation. This course was taught, under authorization, in the universities that had the competency to teach it.

The course, created to train new managers in concepts of innovative change, was put aside with the 2008 crisis, since now the concerns were different. The aim was now to cut and control public spending; and this training policy was, in practice, abandoned with the creation of the Commission for Recruitment and Selection for Public Administration (CRESAP) (Law 64/2011, of 22 December).

A new selection model was established based on merit. This model sought to identify candidates by their relative qualities, through the combination of management skills and behavioral skills, as well as their personality and character. They were specifically evaluating five big characteristics: emotional balance, geniality, sociability, ability to adapt to change and humility.

The ability to manage change and innovation was considered a fundamental trait, and attending the course on Senior Management became just an element of curriculum analysis.

Climate and Culture 
The implementation of change necessarily implies the creation of a climate open to the introduction of a new management model (Pollittb, 2015). It is a difficult process, and adaptation is not expected to occur naturally without the intervention of managers. Moreover, it is worth noting that not everyone gains from the internalization of a new model.

The objective of changing the work climate is to translate into a new organizational culture cementing the introduced changes. This takes precedence over the way people interact in an organization and the way they engage in work and organization (Edgar, 1985). According to the same author, if the intention is to change bureaucratic and hierarchical organizations to a post-bureaucratic model, values that emphasize change, flexibility, efficiency and productivity must be adopted in addition.

\section{Values}

Each model has a set of values that identify it. We saw earlier that the substitution of classical management by New Public Management gives priority attention to results, to the detriment of formalities and processes. However, in a 2000 (OCDE, 2000), organized by the OECD, it was found that in the member countries, the values expected by the citizens from their employees were expected in the following order:
1) Impartiality
2) Legality
3) Integrity
4) Transparency
5) Efficiency
6) Responsibility
7) Justice

This means that the characteristic values of the New Public Management (efficiency and results) were not a priority for citizens. Citizens gave preference to the characteristic values of classical administration.

\section{Creating Incentives}

These incentives may have a pecuniary character, depending on the result of the performance evaluation, but they can also be of a moral nature, based on prestige.

In Portugal, the Administrative Modernization Agency (AMA) created a system of incentives for administrative modernization (SAMA) with the following objectives (Ordinance 186/2018, of 27 June):

- Support for the development of experimental projects

- Awards for innovative management projects

- Improved access to ICT

- Strengthening the institutional capacity of public authorities to carry out reforms in the field of competitiveness

Incentives can go up to $85 \%$ of expenses and can involve the following projects:

- Promotion of network administration 
- Actions for experimentation and dissemination of innovative uses of ICT

- Actions aimed at disseminating best practices

- Development of systems for assessing service delivery and user satisfaction.

As can be easily seen, this policy is not linked to any public management model.

\section{Quality management}

One of the fundamental concerns of the Portuguese Public Administration has been, for a long time, the implementation of quality management. The objective was to involve citizens in the process of administrative modernization. The first step was to create quality control charts. Specific goals, regarding the implementation of the provision of services, were assumed towards any given organization's users. Later in at the initiative of the General Directors of Public Administration of European countries, the European Foundation for Quality Management (EFQM) was adopted, having been adjusted to public services under the nomenclature of Common Assessment Framework (CAF).

The objective was to confront the demands of citizens with the provision of services by officials (Rocha, 2011). This policy gained such relevance in Portugal that the OECD dedicated a special edition to Portugal, in which it emphasized the importance of this instrument for managing administrative reform (OCDE, 1996). It was said on page 11 of the study that change is not just about changing structures, but must be targeted at citizens and treated as customers.

Of course, this strategy was part of a modernization and rationalization policy, but citizens must play a fundamental role in the innovation process.

\section{Establishment of executive agencies}

After a phase of reforms, the British found that they were not achieving the desired results. They then created the Next Steps Initiative, which consisted of fragmenting large administrative units and converting them into agencies.

An agency is defined as an executive unit that provides a service to the State and for which it is paid. This process allows for competition, and consequently, bonuses depending on performance (Rocha, 2010).

In Portugal, the same objective was pursued with the conversion of hospitals into state-owned enterprises.

\section{Conclusion}

Public management models typically mean leaps of innovation in the way public services are managed. In truth, however, the New Public Management was a great moment of rupture and meant the creation of new structures, importation of business management techniques, new forms of remuneration based on the evaluation of performance and internalization of new values.

A formalistic culture, without looking at the needs of the citizen, was followed by a culture geared towards customer satisfaction and concerned with results. "Value for money", as the English says.

It is also important to underline that the task of change is the responsibility of 
management, which, under the impulse of political power, and pressured by citizens, uses instruments and incentives, in order to change the management paradigm.

\section{Conflicts of Interest}

The authors declare no conflicts of interest regarding the publication of this paper.

\section{References}

Clausen, T., \& Mehmet, D. (2020). Intensity of Innovation in Public Sector Organizations: The Role of Push and Pulse Factors. Public Administration Review, 98, 159-176. https://doi.org/10.1111/padm.12617

Damanpour, F., \& Schneider, M. (2011). Characteristics of Innovation and Innovation Adoption in Public Organizations: Assessing the Role of Managers. Journal of Public Administration Research and Theory, 19, 495-522. https://doi.org/10.1093/jopart/mun021

Drucker, P. (1986). Inovação e Gestão. Lisboa: Editorial Presença.

Edgar, S. (1985). Organizational Culture and Leadership. San Francisco, CA: Jossey Bass.

Gieske, H., George, B., van Meerkerk, I., \& van Buuren, A. (2020). Innovation and Optimizing in Public Organizations Does Become Less. Public Management Review, 22, 475-497. https://doi.org/10.1080/14719037.2019.1588356

Hartley, J. (2005). Innovation in Governance and Public Services: Past and Present. Public Money \& Management, 25, 27-34.

Hood, C. (1991). A Public Administration for All Seasons? Public Administration, 69, 3-19. https://doi.org/10.1111/j.1467-9299.1991.tb00779.x

Kickert, W. (2008). The Study of Public Management in Europe and the US: A Competitive Analysis of National Distinctiveness. London: Rouledge.

Lapuente, V., \& Suzuki, K. (2020). Politization, Bureacratic Legalism, and Innovative Attitudes in Public Sector. Public Administration Review, 80, 454-467.

https://doi.org/10.1111/puar.13175

Lewin, K. (1951). Field Theory of Social Science. London: Tavistock Publications.

OCDE (Organisation for Economic Co-Operation and Development) (1996). Priorité aux Citoyens: La réforme de la gestion publique au Portugal. Volume Études hors série sur la Gestion Publique No. 13. Paris: Organisation for Economic Co-Operation and Development.

OCDE (Organisation for Economic Co-Operation and Development) (2000). Trust in Governament: Ethics Measures in OECD Countries. Paris: Organisation for Economic Co-Operation and Development.

Rocha, J. A. O. (2010). Gestão de Recursos Humanos na Administração Pública (3th ed.). Lisboa: Escolar Editora.

Rocha, J. A. O. (2011). Gestão da Qualidade-Aplicação aos Serviços Públicos (2th ed.). Lisboa: Escolar Editora.

Rocha, J. A. O., \& Araujo, J. F. F. de (2007). Administrative Reform in Portugal: Problems and Prospects. International Review of Administrative Sciences (IRAS), 73, 583-596. https://doi.org/10.1177\%2F0020852307083461

Osborne, S. P., \& Brown, K. (2005). Managing Change and Innovation in Public Service 
Organizations. London: Routledge.

Osborne, S. P., \& Brown, L. (2011). Innovation, Public Policy and Public Services Delivery in the UK. The Word That Would Be King? Public Administration, 89, 1335-1350. https://doi.org/10.1111/j.1467-9299.2011.01932.x

Peters, B. G. (2008). The Napoleonic Tradition. International Journal of Public Sector Management, 21, 118-132. https://doi.org/10.1108/09513550810855627

Pollitt, C. (2015). Wickedness Will Not Wait: Climate Change and Public Management Research. Public Money \& Management, 35, 181-186. https://doi.org/10.1080/09540962.2015.1027490

Pollitt, C., \& Bouckaert, G. (2011). Public Management Reform: A Comparative Analysis-New Public Management, Governance, and the Neo-Weberian State (3th ed.). Oxford: Oxford University Press.

Rodrigues, C. (2011). Governação das Organizações Públicas em Portugal: A emergência de modelos diferenciados. s.l.: Edições Pedago.

Vries, H. D., Tummers, L., \& Bekkers, V. (2016). Innovation in the Public Sector: A Systematic Review and Future Research Agenda. Public Administration, 94, 146-166. https://doi.org/10.1111/padm.12209

Wilson, W. (1887). The Study of Administration. Political Science Quarterly, 2, 197-222. https://doi.org/10.2307/2139277 